\title{
How the College works
}

\section{The Fellowship of the Royal College of Psychiatrists and related matters}

\author{
C. Thompson
}

Among the Royal Colleges the criteria for eligibility for the Fellowship varies considerably. In some it is the postgraduate examination itself for example the FRCS. In others it is almost an automatic entitlement of Members who are consultants of good standing and reasonable seniority - for example the FRCP.

The Royal College of Psychiatrists has a Fellowship by election and this article is written to inform Members about the criteria and mechanisms, some of which have recently undergone some small modifications.

Members of the College who have been consultants for at least five years can be put forward by two of their colleagues who are themselves Fellows and who act as their sponsors by completing a citation form. It is quite in order for Members to approach potential sponsors themselves, rather than waiting for election to be suggested. The citation forms arrive at the College in a steady trickle throughout the year but with a deadline each year of 30 September. They are all considered by the Fellowship SubCommittee of which I am the Chairman, which then reports to the Court of Electors with its recommendations, and with a list of those who might need further detailed consideration. Thus the final decision rests, as with all other matters of qualification and election, with the Court.

The Sub-Committee and the Court take the contents of the citation form very seriously as often it is the only information we have about a Member apart from whether or not they are up to date with their subscription! Fellows who complete citation forms should therefore take considerable care to do justice to their colleagues' contributions.

The College's Bye Laws (which have to be approved by the Privy Council, not just the College Council) contain the basic criteria within which both Committees work. These refer to a candidate needing to demonstrate 'a significant contribution to psychiatry', particularly to the work of the College, since becoming a consultant. Research work, education and management responsibilities all count highly and the weight placed on each depends partly upon whether it is seen to be over and above the basic demands of the job.

\section{Fairness or bias?}

We have recently reviewed the composition of the Fellowship of the College in terms of ethnicity and gender in an attempt to discover any hidden biases which might exist within this system. The broad figures are these.

There are 1257 Fellows, who make up $22.2 \%$ of the total College Membership; $10.5 \%$ of all Members are from ethnic minorities. This is defined according to the Office of Population Censuses and Surveys (OPCS) criteria and was collected for the College's ethnic monitoring exercise. We have no information on the ethnicity of $22.9 \%$ of Members so this figure could be inaccurate. Of the Fellows, $8.2 \%$ are from ethnic minorities (with no information on $16.5 \%$ ). So as far as we can tell the Members from ethnic minorities are about as likely to be elected to the Fellowship as their 'white' counterparts and this is a just reflection of the composition of important committees, such as the Board of Examiners for Parts One and Two of the Membership examination, the Council and other senior and executive committees of the College.

However, while $34.5 \%$ of all College Members are female, only $14.9 \%$ of Fellows are female (we have full information on gender). Female psychiatrists therefore appear at first sight to be underrepresented in the Fellowship.

Why do female psychiatrists appear to fare badly in the Fellowship selection processes? We have analysed the citations which have been received for Fellowship since 1990 to determine whether it is because of a lack of citations or because of a higher rate of rejection by the Committee.

Table 1 shows the number and per cent of all citations for female Members and their success rate compared to males since 1990 . It can be seen that in spite of some fluctuations across the years the relative success rate when the citations reach the committee is rather higher than for males. This is shown graphically in Figs 1 and 2. There therefore appears to be no bias against females in the Fellowship Sub-Committee or the Court of Electors. The difference between males and females must arise in the number of citations received. It has been suggested that the lack of 


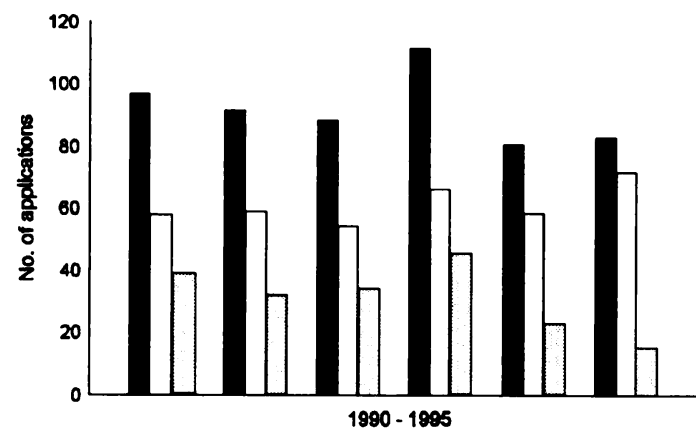

Fig. 1. Male applications to Fellowship, 1990-1995. $\square$, Received; $\square$, elected; $\square$, rejected.

citations for female psychiatrists is a cohort effect, i.e. that the higher output of female doctors from medical school is only now beginning to reach the stage at which they are making up a sizeable proportion at the more senior levels of the profession. There is ample evidence for this in the average ages of the male and female Membership which is 50 for males and 43 for females.

Table 2 demonstrates the critical effect of this seven year difference in age. It shows data for UK applications by age for males and females (overseas applications are more complicated to process and fewer in number so have been excluded). As expected, the success rate for females is higher than males in each decade except the 30s (but this discrepancy is accounted for by only one male individual). For both genders the 40 s are the years in which the majority of Fellowships are awarded. Thus, other things being equal, female psychiatrists should reach equality in the Fellowship in the next seven years.

However, the data in Table 2 also show that female psychiatrists are more likely to be proposed in their 50s and 60s than are males and less likely to be proposed in their 30 s and 40 s. This may suggest that some female professionals spend some of the early and middle years of their career involved with domestic matters and are thus in a worse position to make 'a significant

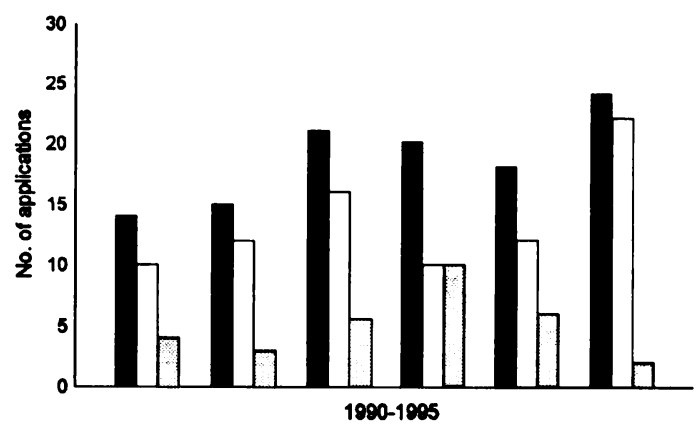

Fig. 2. Female applications to Fellowship, 1990 1995. $\square$, Received; $\square$, elected; $\square$, rejected.

contribution to psychiatry' than their male counterparts until a later age. Although we have no direct data on the age at which male and female consultants first become active on the wider professional stage we do know that $24 \%$ of Members of Council, 27\% of Regional Advisers (or Deputies), $26 \%$ of Part One examiners and $14 \%$ of Part Two examiners are female. Since $34.5 \%$ of the whole Membership is female this suggests that female Members of the College are less likely to be engaged in College activities at a high level, which might suggest either a cohort effect, a disinclination for such work, possibly due to other commitments or indeed discrimination against them when College posts are being filled. It is also possible that female psychiatrists are less likely to request to be put up for the Fellowship than males and may be more likely to wish actively to remain a Member.

\section{Recent changes to the procedures}

Whatever the reasons behind the lower than expected numbers of female Fellows, the important point is that every Member of the College should have an equal opportunity to be considered for the Fellowship. Because of concerns about under-representation of psychiatrists from outside the main teaching centres we are now regularly sending a list of the names of those

Table 1. Applications to the Fellowship and their success rates for male and female Members from 1990 to 1995

\begin{tabular}{|c|c|c|c|c|c|c|c|}
\hline \multicolumn{2}{|l|}{ Year } & 1990 & 1991 & 1992 & 1993 & 1994 & 1995 \\
\hline \multicolumn{8}{|c|}{ Applications } \\
\hline Male & $\begin{array}{l}n \\
\%\end{array}$ & $\begin{array}{l}97 \\
87.4\end{array}$ & $\begin{array}{l}91 \\
85.8\end{array}$ & $\begin{array}{l}88 \\
80.7\end{array}$ & $\begin{array}{c}111 \\
84.7\end{array}$ & $\begin{array}{l}80 \\
81.6\end{array}$ & $\begin{array}{l}82 \\
77.4\end{array}$ \\
\hline Female & $\begin{array}{l}n \\
\%\end{array}$ & $\begin{array}{l}14 \\
12.6\end{array}$ & $\begin{array}{l}15 \\
14.2\end{array}$ & $\begin{array}{l}21 \\
19.3\end{array}$ & $\begin{array}{l}20 \\
15.3\end{array}$ & $\begin{array}{c}18 \\
184\end{array}$ & $\begin{array}{l}24 \\
22.6\end{array}$ \\
\hline \multicolumn{8}{|c|}{ Success rates } \\
\hline Male & $\begin{array}{l}n \\
\%\end{array}$ & $\begin{array}{l}58 \\
59.8\end{array}$ & $\begin{array}{l}59 \\
64.8\end{array}$ & $\begin{array}{l}54 \\
61.4\end{array}$ & $\begin{array}{l}66 \\
59.5\end{array}$ & $\begin{array}{l}58 \\
72.5\end{array}$ & $\begin{array}{l}71 \\
86.6\end{array}$ \\
\hline Female & $\begin{array}{l}n \\
\%\end{array}$ & $\begin{array}{l}10 \\
71.4\end{array}$ & $\begin{array}{l}12 \\
80.0\end{array}$ & $\begin{array}{l}16 \\
76.2\end{array}$ & $\begin{array}{l}10 \\
50.0\end{array}$ & $\begin{array}{l}12 \\
66.7\end{array}$ & $\begin{array}{l}22 \\
91.7\end{array}$ \\
\hline
\end{tabular}


Table 2. Total applications and success rates from 1990 to 1995 in each decade of professional life for males and females

\begin{tabular}{llllll}
\hline & Males & & & \multicolumn{2}{l}{ Females } \\
\cline { 3 - 4 } \cline { 5 - 6 } Age & $\begin{array}{l}\text { Number } \\
\text { (\% of total) }\end{array}$ & $\begin{array}{l}\text { Success } \\
\text { Rate (\%) }\end{array}$ & $\begin{array}{l}\text { Number } \\
\text { (\% of total) }\end{array}$ & $\begin{array}{c}\text { Success } \\
\text { Rate (\%) }\end{array}$ \\
\hline 305 & $7(16)$ & 14 & $2(2)$ & 0 \\
405 & $254(59)$ & 68 & & $52(50)$ & 69 \\
505 & $141(33)$ & 74 & $38(36)$ & 79 \\
605 & $\times 31(7)$ & 84 & $12(11)$ & 92 \\
\hline
\end{tabular}

psychiatrists in each region who have been consultants for more than five years (but who are not yet Fellows) to the Chairman of the College division and the Regional Adviser. It is the duty of these Officers in consultation with other senior local figures to put forward the names of those Members of good standing who have been consultants for more than five years and who wish their names to be considered. This already happens in some Divisions. If used properly it should ensure that no colleague is passed over for recognition of their contributions by award of the Fellowship. We do not however intend to make the election automatic after five years, since that would introduce a marked difference between the meaning of Fellowships awarded before and after 1994/5 which would be invidious. We still wish Fellows to cherish their title as a recognition of distinguished service, the lack of which does not reflect badly on those who do not have it. Furthermore some Members do not wish to be considered for the Fellowship and this should be respected.

\section{Membership under Bye Law 3 (m)2}

This little known route to Membership is seldom used but up to ten new Members can be created in this way each year. The only absolute bar is to have failed the Membership examination and this is to ensure that it is not used as a back door to Membership by those who have failed all attempts.

The criteria used are however higher than for Membership by examination and refer to medical candidates of exceptional distinction. They are generally in line with the criteria for Fellowship and often Members under this rule are made up to Fellows rapidly. Like Fellowship, two sponsors are required to complete a citation form. Membership under this Bye Law can be offered to Members of other medical disciplines working in the UK, distinguished psychiatrists working abroad, within or beyond the EU, or to nonMember consultant psychiatrists in the UK who have never failed the Membership examination.
Table 3. Honorany Fellows

\begin{tabular}{|c|c|}
\hline 1995 & $\begin{array}{l}\text { Dr A. Coppen } \\
\text { Professor C. M. Plerce } \\
\text { Professor G. Russell } \\
\text { Dr R. Sadoun } \\
\text { Duchess of Kent }\end{array}$ \\
\hline 1994 & $\begin{array}{l}\text { Professor Hanns Hipplus } \\
\text { Professor Felice Lieh Mak } \\
\text { Professor Andrew Sims } \\
\text { Dr John Reed } \\
\text { Professor Sir John Wood }\end{array}$ \\
\hline 1993 & $\begin{array}{l}\text { The Rt Hon. Lady Falthfull } \\
\text { Professor Leonard Stein } \\
\text { Dr Anthony Storr } \\
\text { Judge Stephen Tumim } \\
\text { Lord John Walton of Detchant }\end{array}$ \\
\hline 1992 & $\begin{array}{l}\text { The Rt Hon. Dame Elizabeth Butler-Sloss } \\
\text { Dr Phillip Connell } \\
\text { Mrs Mary Robinson (President of Ireland) } \\
\text { Dr Melvin Sabshin } \\
\text { Professor George Winokur }\end{array}$ \\
\hline 1991 & $\begin{array}{l}\text { HRH The Prince of Wales } \\
\text { Dr J. L. T. Birley } \\
\text { The Lord Ennals } \\
\text { Sir Raymond Hoffenberg } \\
\text { Professor Narendra N. Wig }\end{array}$ \\
\hline 1990 & $\begin{array}{l}\text { Professor Robert Cawley } \\
\text { Dr Eric Cummingham Dax } \\
\text { Professor Lee Robins } \\
\text { Dame Rosemary Rue } \\
\text { Professor Michael Shepherd }\end{array}$ \\
\hline
\end{tabular}

Since 1990 there have been 30 new Members created under this rule.

\section{The Honorary Fellowship}

The Honorary Fellowship is the highest honour the College can bestow and up to five are created each year. The list of those created since 1990 is shown in Table 3.

\section{Affiliates}

The category of Affiliates of the College has been created by a Bye Law change in 1995. This allows up to $\mathbf{7 0 0}$ psychiatrists who are not in training grades and are not Members of the College to be Affliates at any one time. They will not be allowed to use the letters ARCPsych, which will have no meaning. They will however benefit from their association with the College by better access to continuing professional development, the journals and other professional activities. They will be represented on Council. Further information about Affiliate status can be obtained from the Postgraduate Education Department.

C. Thompson, Registrar, Royal College of Psychiatrists 